\title{
Improvement of Impact Toughness and Abrasion Resistance of a 3C-25Cr-0.5Mo Alloy Using a Design of Experiment Statistical Technique: Microstructural Correlations after Heat Treatments
}

\author{
Alejandro González-Pociño ${ }^{1, *(\mathbb{C})}$, Juan Asensio-Lozano ${ }^{1}\left(\mathbb{D}\right.$, Florentino Álvarez-Antolín ${ }^{1}(\mathbb{C}$ \\ and Ana García-Diez $2, * \mathbb{D}$ \\ 1 Materials Pro Group, Departamento de Ciencia de los Materiales e Ingeniería Metalúrgica, \\ Universidad de Oviedo, Independencia 13, 33004 Oviedo, Spain; jasensio@uniovi.es (J.A.-L.); \\ alvarezflorentino@uniovi.es (F.Á.-A.) \\ 2 Departamento de Ingeniería Naval e Industrial, Escuela Politécnica Superior, \\ Universidad de A Coruña, 15403 Ferrol, Spain \\ * Correspondence: gonzalezpalejandro@uniovi.es (A.G.-P.); ana.gdiez@udc.es (A.G.-D.)
}

Citation: González-Pociño, A.; Asensio-Lozano, J.; Álvarez-Antolín, F; García-Diez, A. Improvement of Impact Toughness and Abrasion Resistance of a 3C-25Cr-0.5Mo Alloy Using a Design of Experiment Statistical Technique: Microstructural Correlations after Heat Treatments. Metals 2021, 11, 595. https:// doi.org/10.3390/met11040595

Received: 9 March 2021

Accepted: 2 April 2021

Published: 6 April 2021

Publisher's Note: MDPI stays neutral with regard to jurisdictional claims in published maps and institutional affiliations.

Copyright: (c) 2021 by the authors. Licensee MDPI, Basel, Switzerland. This article is an open access article distributed under the terms and conditions of the Creative Commons Attribution (CC BY) license (https:// creativecommons.org/licenses/by/ $4.0 /)$.

\begin{abstract}
Hypoeutectic high chromium white cast irons are commonly used in the mining and cement industries, where high resistance to abrasive wear is demanded. Through the application of a Design of Experiment technique (DoE), different factors related to thermal industrial treatments are analysed with regard to resistance to abrasive wear and impact response. Abrasion tests were carried out in accordance with the ASTM G065-16 standard. The provisional results show that to increase wear resistance, high destabilisation temperatures $\left(1050^{\circ} \mathrm{C}\right)$ followed by slow cooling to room temperature (RT) and subsequent tempering at $400{ }^{\circ} \mathrm{C}$ are most favourable. This is because these conditions are favourable to maintaining a certain tetragonality of the martensite after tempering and also, because of the presence of a high density of mixed carbides $\mathrm{M}_{7} \mathrm{C}_{3}$, through a secondary precipitation during cooling. Oil quenching and a high tempering temperature $\left(550{ }^{\circ} \mathrm{C}\right)$ with long dwell times of $6 \mathrm{~h}$ were found to increase impact toughness. These conditions favour a lack of retained austenite. The presence of retained austenite was found unfavourable for both wear resistance and toughness, whereas tempering at $400{ }^{\circ} \mathrm{C}$ has been shown to be insufficient to transform martensite on tempering, which in turn seemed to increase the hardness of the matrix constituent.
\end{abstract}

Keywords: white cast irons with $25 \% \mathrm{Cr}$; resistance to abrasive wear; impact toughness; microstructure correlation; destabilisation of austenite; secondary carbides

\section{Introduction}

White cast irons with a high chrome content and which have a composition defined by ASTM A532 111A [1] are widely used in the crushing and grinding of rocks and minerals in the mining and construction industries [2-4]. Resistance to abrasive and erosive wear, as well as resistance to corrosion, are critical properties for such aggressive applications [5,6]. It is also necessary for these cast irons to show a good balance between wear resistance and impact toughness, given that in the mining industry they are used, for example, as inner linings of tumble mills used for grinding. The repetitive conditions to which they are exposed include continuous sliding and frequent low impact falls of the ores being treated [7].

The chemical composition for these abrasion resistant alloys yields a hypoeutectic microstructure in the as-cast condition, where the solidification temperature is around $1265^{\circ} \mathrm{C}$ [8]. Solidification starts with the formation of primary austenite dendrites and to the conclusion of the eutectic solidification becomes the primary isolated constituent. On reaching room temperature this remained as a dispersed constituent, partially transformed in the solid state, surrounded by a eutectic matrix. Such an eutectic phase is composed of a 
mixture of austenite and $\mathrm{M}_{7} \mathrm{C}_{3}$ carbides of the mixed type ( $\left.\mathrm{Cr}, \mathrm{Fe}\right)_{7} \mathrm{C}_{3}$ [9]. The hardness values of these types of cast irons vary between 500 and $520 \mathrm{HV}$ in the as-cast state [10]. The abrasion resistance of white cast irons with a high chrome content depends, among other factors, on the $\mathrm{Cr}: \mathrm{C}$ ratio, the thermal treatment history and the type of carbides present, as well as on the hardness, morphology, distribution and its volume fraction [11-13]. Other factors which influence wear resistance include the size and shape of the abrasive ore particles [14], the orientation of the carbide in relation to the direction of wear [15] and the context of wear itself [16]. It is essential to take into account that carbides of the type $\mathrm{M}_{7} \mathrm{C}_{3}$ are more preferable to any other type, like $\mathrm{M}_{3} \mathrm{C}, \mathrm{M}_{23} \mathrm{C}_{6}$ and $\mathrm{M}_{6} \mathrm{C}$, because they tend to be coarse and continuous. Ideally, the primary austenite should be uniformly surrounded by the eutectic phase. Within the eutectic, $(\mathrm{Cr}, \mathrm{Fe})_{7} \mathrm{C}_{3}$ carbides represent the discontinuous constituent. The other types of carbides have been found to develop at higher $\mathrm{M}: \mathrm{C}$ ratios [17]. On the other hand, manganese plays an important role in refining the austenite dendrites, and it has been shown to prevent pearlite formation on cooling [18].

Resistance to abrasion also arises from the possibility of austenite hardening when it is subjected to plastic deformation, as is often the case when the surface of the components reacts to repeated impacts on their surface with ores in the mining industry. Moreover, in mining operations with low impact requirements, this type of high $\mathrm{Cr}$ cast iron exhibits a satisfactory performance in the as-cast condition due to a relatively high presence of retained austenite at room temperature, capable of plastically absorbing this energy, as reported in certain applications $[19,20]$. However, excessive energy impacts may cause complete breaking of the components and thus, it explains why they are not suitable for high impact loading [10]. In line with the former, it is a common practice to design cooling paths after destabilization and tempering with the aim of ensuring the maintenance of a minimum percentage of retained austenite so as to avoid harmful effects like surface spalling whilst the main focus is set on the increase of wear resistance [21].

In abrasive wear processes, the hardest phases of the microstructure are normally prone to easy fracture, whereas the softer ones could be either cracked or plastically deformed. Thus, chips of the material could break off from the surface therefore resulting in a measurable volume loss of material [22]. The role of the matrix constituent in the microstructure surrounding isolated eutectic carbides is to provide enough mechanical endurance to suppress or minimize cracking, deformation and chip detachments from the surface. Field observations confirmed that the variations in wear resistance are mainly caused by the changes in hardness that fine carbide precipitation from destabilisation confers, in combination with the possibility of a refined microstructure presence for the other phases [23].

In view of the above, the present research aimed to find a destabilisation treatment of austenite designed to maximize the formation of $\mathrm{Cr}$-rich secondary carbide. Such a target is generally accomplished at temperatures comprised of between 900 and $1100{ }^{\circ} \mathrm{C}$ with dwell times of up to $6 \mathrm{~h}$, depending on the degree of transformation required [24,25]. Heat treatment guides recommend $1 \mathrm{~h}$ of soaking at temperature for each $25 \mathrm{~mm}$ of thickness of the cross section. During the destabilisation treatment of the austenite, two complementary kinetics compete. On one hand, the precipitation of secondary carbides is produced. On the other hand, the dissolution of precipitated eutectic carbides is produced in non-equilibrium solidification. The predominance of one over the other depends on the temperature and dwell time [26]. When the dwell period finishes, cooling in air at room temperature (RT) follows, where a depleted austenite in $\mathrm{Cr}$ and $\mathrm{C}$ partially transforms into martensite [27]. A small fraction of residual austenite could remain at RT along with secondary Cr-rich carbides from destabilisation embedded in it. Such a microstructure could lead to a significant increase in hardness.

Following the above, a tempering heat treatment at temperatures comprised of between 450 and $650^{\circ} \mathrm{C}$ for up to $12 \mathrm{~h}$ is recommended, with the primary objective of ageing martensite and obtaining conditioned austenite [28]. By means of a second tempering treatment, conditioned austenite transforms. During the first tempering treatment resid- 
ual stresses from quenching are removed, thus increasing its toughness [29,30]. Caution should be exercised to avoid coarsening of secondary carbides [9] which may occur if excessive tempering times are used, resulting in a substantial reduction in hardness. The $\mathrm{Cr}$ atoms occupy substitutional positions, and their diffusion is not effective until reaching $500{ }^{\circ} \mathrm{C}[31,32]$.

Through the application of a Design of Experiment (DoE for short) technique based on statistics, the influence on microstructure of the destabilisation temperature at a constant dwell time of $5 \mathrm{~h}$ has been studied. Two different temperatures are analysed, one of $950{ }^{\circ} \mathrm{C}$ and the other of $1050{ }^{\circ} \mathrm{C}$, in order to analyse the influence of precipitation kinetics and the dissolution of eutectic carbides, previously described. Sample cooling with the use of different cooling media and the role of tempering were the other factors evaluated. Two different tempering temperatures are analysed, one under $500{ }^{\circ} \mathrm{C}$ and the other above this temperature. There are two objectives: firstly, to study the influence of the precipitation of carbides $(\mathrm{Cr}, \mathrm{Fe})_{7} \mathrm{C}_{3}$ during tempering, and secondly, to analyse the adjustment and the following transformation of the retained austenite present. All of the above was done with the objective of maximising the resistance to abrasive wear, without impairing toughness.

\section{Materials and Methods}

Based on DoE statistical technique, the thermal treatments of destabilisation and tempering at levels set in a Factorial Fractional study was planned to monitor the effects of the variation of four factors simultaneously. Such factors are related in agreement with the results based on previous studies by the authors. The application of this statistical technique aims to deliberately modify normal working conditions in order to produce changes in some of the studied responses, as would be the case of resistance to wear and toughness. These changes are carried out on certain production factors. The effect of a factor on the variation in the response function is defined as a consequence of the variation of that factor. The main effects are defined as those derived from each separate factor. Occasionally, the value which one factor takes depends on another factor. When this happens, the factors are said to interact. On an industrial level, the importance of the main effects tends to be much greater than the importance of the interactions of two factors, and these, at the same time, greater than the interactions of three factors, and so on. This allows for the simplification of the experimental design and reduces the number of experiments. A complete factorial design needs a total of $2^{4}=16$ experiments. In this study, a factorial design fractioned by half has been used with a total of $2^{3-1}=8$ experiments [33].

The samples used in this study come from the Spanish company Fundiciones del Estanda S.A. (Beasain, Guipúzcoa, Spain). Table 1 shows the basic chemistry of the experimental material, a high chrome cast iron micro-alloyed with molybdenum. The chemical analysis was supplied by the company Fundiciones del Estanda, S.A. Table 2 shows the combination of factors and levels chosen for the study. Table 3 shows the matrix of the experiments corresponding to this study.

Table 1. Chemical Composition (\% in weight).

\begin{tabular}{ccccc}
\hline $\mathbf{C}$ & $\mathbf{S i}$ & $\mathbf{M n}$ & $\mathbf{C r}$ & Mo \\
\hline 2.7 & 1.2 & 0.8 & 25.1 & 0.5 \\
\hline
\end{tabular}

Table 2. Factors and Levels.

\begin{tabular}{cccc}
\hline & Factors & \multicolumn{2}{c}{ Levels } \\
\hline Code & Metallurgical Parameter (Factors) & Level $-\mathbf{1}$ & Level +1 \\
\hline A & Destabilisation temperature of austenite $\left({ }^{\circ} \mathrm{C}\right)$ for $5 \mathrm{~h}$ & 950 & 1050 \\
B & Cooling media from austenite destabilizing & Air convection within a & gently stirred oil at \\
C & furnace set $@ 150{ }^{\circ} \mathrm{C}$ & R.T. & 550 \\
D & Dwell time at tempering temperature $(\mathrm{h})$ & 400 & 6 \\
\hline
\end{tabular}


Table 3. Matrix of Experiments.

\begin{tabular}{cccccc}
\hline No & A & B & C & D & Restricted Confounding Patterns \\
\hline 1 & -1 & -1 & -1 & -1 & A \\
2 & +1 & -1 & -1 & +1 & $\mathrm{~B}$ \\
3 & -1 & +1 & -1 & +1 & $\mathrm{C}$ \\
4 & +1 & +1 & -1 & -1 & $\mathrm{D}$ \\
5 & -1 & -1 & +1 & +1 & $\mathrm{AB}+\mathrm{CD}$ \\
6 & +1 & -1 & +1 & -1 & $\mathrm{AC}+\mathrm{BD}$ \\
7 & -1 & +1 & +1 & -1 & $\mathrm{AD}+\mathrm{BC}$ \\
8 & +1 & +1 & +1 & +1 & \\
\hline
\end{tabular}

The "Restricted Confounding Patterns" column shows the main effects of the factors and the interactions of two factors whose effects are confounded with the main effects. The effects are linear combinations of the analysed responses and, based on the central limit theorem, they follow a normal law distribution. Each main effect may be considered as a random variable, where the value obtained is an estimation of its mean $\mu$, which is accompanied by its standard deviation $\sigma$, noted as: $\mathrm{N}(\mu, \sigma)$. When the effects are not significant, they will follow the normal law $\mathrm{N}(0, \sigma)$, that is to say, with $\mu$ equals zero. When plotting the standardised effects on a normal probability graph, they will appear aligned. However, if one or more effects are significant, they follow a normal law given by $\mathrm{N}(\mu, \sigma)$, with $\mu \neq 0$, and will easily be identified as they would not appear aligned with regard to the non-significant ones [33].

The standardised effect is the quotient between the difference between the variable and its mean over the standard deviation of said variable. This value not only represents whether the variable is above or below the mean, but most important, how big this difference is, i.e., how distant the value of the variable is from the value of the mean. When the significant factors deviate from the straight line to the left side, it shows that at its " -1 " level, the response function increases with respect to its " +1 " level. Conversely, those significant factors which deviate from the straight line to the right side, show that their " +1 " level increases the response function with respect to its " -1 " level.

The analysed responses in the present experimentation were structured in two categories: microstructural characteristics and mechanical properties. They are listed herein after:

- Microstructural features being evaluated:

- Percentage in weight of retained austenite and tempered martensite.

$\bigcirc \quad$ Cell unit volume of tempered martensite

- Percentage in weight of the carbides of the following types $M_{7} C_{3}, M_{23} C_{6}$ and $M_{2} C$.

- Mechanical properties tested:

The Vickers microhardness of the matrix constituent, with $50 \mathrm{gf}(0.49 \mathrm{~N})$, averaging the results of 24 indentations.

- The abrasive wear resistance by means of the dry sand/rubber wheel abrasion test, executed in accordance with the ASTM G065-16 standard, with the following test parameters: Rubber wheel diameter: $228.6 \mathrm{~mm}$; Shore A hardness of rubber: $60 \pm 2$; Silica sand (AF50/70); Sand flow: 300-400 g/min; Rate of revolution: $200 \mathrm{rpm}$; Test time: $30 \mathrm{~min}$.

- High strain-rate impact test in a Hounsfield pendulum on un-notched round bars of $8 \mathrm{~mm}$ in diameter. The test was conducted on 3 un-notched specs typical for brittle materials for each experiment, and its average value reported.

Scanning Electron Microscope (SEM) images were obtained in a JEOL JSM-5600 (JEOL Ltd., Tokyo, Japan) electron microscope and semi-quantitative spectrum analysis of phases were conducted with an energy dispersive X-ray (EDX) microanalyzer connected to the microscope. The microstructural characteristics were quantitatively assessed by X-ray diffraction in a SEIFERT XRD $3000 \mathrm{~T} / \mathrm{T}$ (KU Leuven, Leuven, Belgium) diffractometer. Radiation was emitted through a fine focus located after a Mo emitting tube, operating 
at a working voltage and intensity of $40 \mathrm{kV} \times 40 \mathrm{~mA}$, with monochromatizing to the $\mathrm{K} \alpha$ : $\lambda 1=0.709316 \AA$ and $\lambda 2=0.713607 \AA$. The diffraction intensity was determined at an angle interval $2 \theta$ varying from 7 to $57^{\circ}$. The Rietveld refinement method was used to obtain a more precise determination of the percentage of crystalline phases through the adjustment of the formerly obtained diffractograms. This was carried out using the crystallographic information archives pertaining to the Inorganic Crystal Structure Database (ICSD) by FIZKarlsruhe, Germany. The software package used to perform the Rietveld enhancement was FullProf.2k, version 6.20 (2018). The increase in width observed for the peaks of the main phases, was modelled using the formulation after Stephens [34], which was implemented prior to running the software program for Rietveld enhancement of crystalline phase peaks.

\section{Results}

Figure 1 shows the diffractograms obtained after Rietveld structural refinement. The intensities are highlighted in red, the calculated intensity, according to the Rietveld model, is presented in black, and the difference between the two intensities are drawn in blue. The vertical segments indicate the angular positions of the different phases being identified.

Table 4 shows the percentages in weight of the main crystalline phases detected by $\mathrm{X}$-ray diffraction. The goodness of the fit is assessed by the Rwp agreement factor, the Rexp index, and its squared ratio, $\mathrm{Chi}^{2}=(\mathrm{Rwp} / \mathrm{Rexp})^{2}$. The volume of the unaged martensite cell after specific tempering expressed in cubic Armstrong has also been quoted.

Table 4. Distribution in weight of carbides, martensite and austenite, and cell volume of austenite. Statistical error is indicated in parenthesis.

\begin{tabular}{|c|c|c|c|c|}
\hline Experiment & $\begin{array}{c}\text { Rietveld } \\
\text { Refinement }\end{array}$ & Phases & $\begin{array}{c}\text { Lattice Volume of } \\
\text { Martensite }\left(\AA^{3}\right)\end{array}$ & wt. \% \\
\hline 1 & $\begin{array}{l}\operatorname{Rwp}=11.6 \\
\operatorname{Rexp}=7.40 \\
\mathrm{Chi}^{2}=2.46\end{array}$ & $\begin{array}{c}\text { Martensite } \\
\text { Austenite } \\
\mathrm{M}_{7} \mathrm{C}_{3} \text { carbide } \\
\mathrm{M}_{2} \mathrm{C} \text { carbide }\end{array}$ & $\begin{aligned} 23.58 & ( \pm 0.006) \\
& - \\
& - \\
& -\end{aligned}$ & $\begin{array}{c}54.64( \pm 1.99) \\
5.61( \pm 0.62) \\
38.86( \pm 1.45) \\
0.90( \pm 0.13)\end{array}$ \\
\hline 2 & $\begin{array}{c}\operatorname{Rwp}=15.6 \\
\operatorname{Rexp}=7.15 \\
\mathrm{Chi}^{2}=4.79\end{array}$ & $\begin{array}{c}\text { Martensite } \\
\text { Austenite } \\
\mathrm{M}_{7} \mathrm{C}_{3} \text { carbide } \\
\mathrm{M}_{2} \mathrm{C} \text { carbide }\end{array}$ & $\begin{aligned} 23.67 & ( \pm 0.005) \\
& - \\
& - \\
& -\end{aligned}$ & $\begin{array}{c}20.99( \pm 0.66) \\
9.70( \pm 0.8) \\
68.83( \pm 1.82) \\
0.48( \pm 0.09)\end{array}$ \\
\hline 3 & $\begin{array}{c}\operatorname{Rwp}=10.5 \\
\operatorname{Rexp}=7.84 \\
\mathrm{Chi}^{2}=1.81\end{array}$ & $\begin{array}{c}\text { Martensite } \\
\text { Austenite } \\
\mathrm{M}_{7} \mathrm{C}_{3} \text { carbide } \\
\mathrm{M}_{2} \mathrm{C} \text { carbide }\end{array}$ & $\begin{aligned} 23.61 & ( \pm 0.006) \\
& - \\
& - \\
& -\end{aligned}$ & $\begin{array}{c}68.07( \pm 2.53) \\
6.22( \pm 0.34) \\
25.06( \pm 0.94) \\
0.65( \pm 0.07)\end{array}$ \\
\hline 4 & $\begin{array}{l}\operatorname{Rwp}=11.3 \\
\operatorname{Rexp}=7.19 \\
\mathrm{Chi}^{2}=2.48\end{array}$ & $\begin{array}{c}\text { Martensite } \\
\text { Austenite } \\
\mathrm{M}_{7} \mathrm{C}_{3} \text { carbide } \\
\mathrm{M}_{2} \mathrm{C} \text { carbide }\end{array}$ & $\begin{aligned} 23.64 & ( \pm 0.01) \\
& - \\
& - \\
& -\end{aligned}$ & $\begin{array}{c}53.85( \pm 2.30) \\
18.16( \pm 0.89) \\
27.40( \pm 1.15) \\
0.58( \pm 0.11)\end{array}$ \\
\hline 5 & $\begin{aligned} \operatorname{Rwp} & =14.4 \\
\operatorname{Rexp} & =8.63 \\
\mathrm{Chi}^{2} & =2.78\end{aligned}$ & $\begin{array}{c}\text { Martensite } \\
\text { Austenite } \\
\mathrm{M}_{7} \mathrm{C}_{3} \text { carbide } \\
\mathrm{M}_{2} \mathrm{C} \text { carbide }\end{array}$ & $\begin{aligned} 23.53 & ( \pm 0.003) \\
& - \\
& - \\
- & \end{aligned}$ & $\begin{array}{c}69.47( \pm 3.05) \\
0.40( \pm 0.32) \\
29.50( \pm 1.26) \\
0.63( \pm 0.13)\end{array}$ \\
\hline 6 & $\begin{array}{l}\operatorname{Rwp}=11.9 \\
\operatorname{Rexp}=7.35 \\
\mathrm{Chi}^{2}=2.60\end{array}$ & $\begin{array}{c}\text { Martensite } \\
\text { Austenite } \\
\mathrm{M}_{7} \mathrm{C}_{3} \text { carbide } \\
\mathrm{M}_{2} \mathrm{C} \text { carbide }\end{array}$ & $\begin{aligned} 23.61 & ( \pm 0.005) \\
& - \\
- & - \\
& \end{aligned}$ & $\begin{array}{c}46.36( \pm 1.78) \\
1.12( \pm 0.39) \\
52.09( \pm 1.45) \\
0.43( \pm 0.09)\end{array}$ \\
\hline 7 & $\begin{array}{l}\operatorname{Rwp}=20.7 \\
\operatorname{Rexp}=9.96 \\
\mathrm{Chi}^{2}=4.33\end{array}$ & $\begin{array}{c}\text { Martensite } \\
\text { Austenite } \\
\mathrm{M}_{7} \mathrm{C}_{3} \text { carbide } \\
\mathrm{M}_{2} \mathrm{C} \text { carbide }\end{array}$ & $\begin{aligned} 23.56 & ( \pm 0.001) \\
& - \\
& - \\
& -\end{aligned}$ & $\begin{array}{c}23.69( \pm 0.38) \\
0.1( \pm 0.08) \\
76.11( \pm 1.68) \\
0.10( \pm 0.02)\end{array}$ \\
\hline 8 & $\begin{aligned} \operatorname{Rwp} & =11.8 \\
\operatorname{Rexp} & =8.34 \\
\mathrm{Chi}^{2} & =2.00\end{aligned}$ & $\begin{array}{c}\text { Martensite } \\
\text { Austenite } \\
\mathrm{M}_{7} \mathrm{C}_{3} \text { carbide } \\
\mathrm{M}_{2} \mathrm{C} \text { carbide }\end{array}$ & $\begin{aligned} 23.53 & ( \pm 0.005) \\
& - \\
& - \\
& -\end{aligned}$ & $\begin{array}{c}64.73( \pm 2.51) \\
0.99( \pm 0.18) \\
34.03( \pm 1.14) \\
0.24( \pm 0.09)\end{array}$ \\
\hline
\end{tabular}



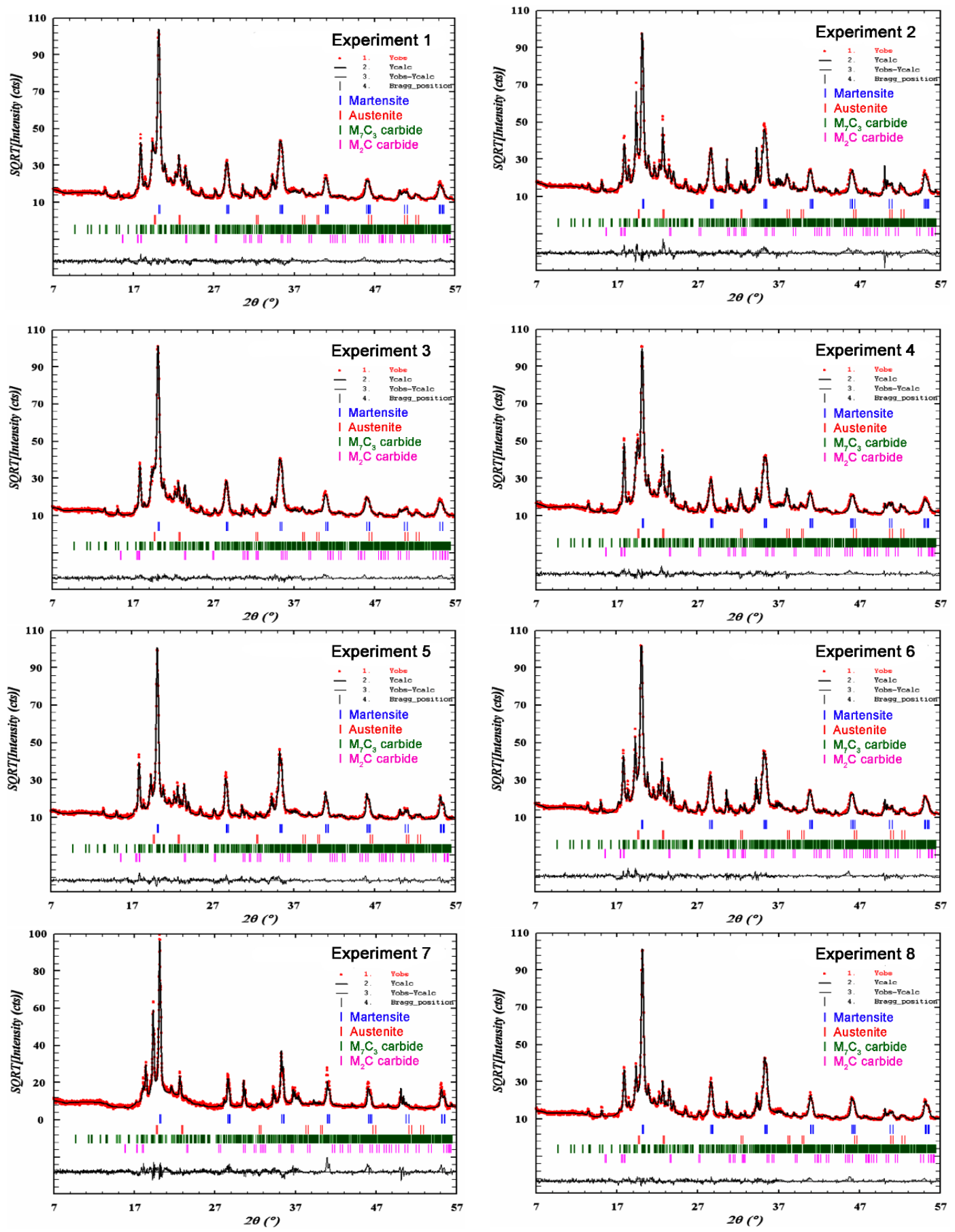

Figure 1. Diffractograms of the experiments after Rietveld refinement.

Table 5 shows a last column entitled "confounding pattern" for which each line (row) corresponds one to one with the numerical values in the columns of the standardised effects. In such fashion, the first numerical value in the column of the standardised effects is always the average of the responses. Values in parenthesis represent the error of the mean given by its standard deviation. Figure 2 depicts the representation of the standardised effects on a normal probability graph, and following the usual practice, for reasons of simplicity, only the factors with a significant effect on the responses are labelled. 
Table 5. Average values and obtained effects for the precipitated phases.

(a) Weight percentage of tempered martensite and retained austenite

\begin{tabular}{|c|c|c|c|c|c|c|c|}
\hline \multirow{2}{*}{$\begin{array}{c}\text { Experiment } \\
\text { Number }\end{array}$} & \multicolumn{2}{|c|}{ Austenite } & \multicolumn{4}{|c|}{ Martensite } & \multirow{2}{*}{$\begin{array}{l}\text { Confounding } \\
\text { Pattern }\end{array}$} \\
\hline & wt.\% & Effects & wt. $\%$ & Effects & vol. $\%$ & Effects & \\
\hline 1 & 5.61 & 5.29 & 54.64 & 50.23 & 23.58 & 23.58 & Average \\
\hline 2 & 9.70 & 4.41 & 20.99 & -7.49 & 23.67 & 0.04 & A \\
\hline 3 & 6.22 & 2.16 & 68.07 & 4.72 & 23.60 & -0.01 & B \\
\hline 4 & 18.16 & -9.27 & 53.85 & 1.68 & 23.64 & -0.07 & $\mathrm{C}$ \\
\hline 5 & 0.40 & -1.92 & 69.47 & 11.18 & 23.53 & -0.01 & $\mathrm{D}$ \\
\hline 6 & 1.12 & 2.01 & 46.36 & 20.90 & 23.6 & -0.04 & $\mathrm{AB}+\mathrm{CD}$ \\
\hline 7 & 0.10 & -3.61 & 23.69 & 16.45 & 23.56 & -0.02 & $\mathrm{AD}+\mathrm{BC}$ \\
\hline 8 & 1.00 & -2.38 & 64.73 & -18.43 & 23.53 & -0.01 & $\mathrm{AC}+\mathrm{BD}$ \\
\hline
\end{tabular}

(b) Weight percentage of $\mathrm{M}_{7} \mathrm{C}_{3}$ and $\mathrm{M}_{2} \mathrm{C}$ carbides

\begin{tabular}{cccccc}
\hline \multirow{2}{*}{$\begin{array}{c}\text { Experiment } \\
\text { Number }\end{array}$} & \multicolumn{2}{c}{$\mathbf{M}_{\mathbf{7}} \mathbf{C}_{\mathbf{3}}$ Carbide } & & $\mathbf{M}_{\mathbf{2}} \mathbf{C}$ Carbide & \multicolumn{2}{c}{$\begin{array}{c}\text { Confounding } \\
\text { Pattern }\end{array}$} \\
\cline { 2 - 6 } & $\mathbf{w t .} \%$ & Effects & $\mathbf{w t .} \%$ & 0.50 & Average \\
\hline 1 & 38.86 & 44.00 & 0.89 & -0.14 & $\mathrm{~A}$ \\
2 & 68.83 & 3.21 & 0.48 & -0.22 & $\mathrm{~B}$ \\
3 & 25.06 & -6.67 & 0.65 & -0.30 & $\mathrm{C}$ \\
4 & 27.40 & 7.90 & 0.59 & 0.00 & $\mathrm{D}$ \\
5 & 29.50 & -9.26 & 0.63 & 0.17 & $\mathrm{AB}+\mathrm{CD}$ \\
6 & 52.09 & -23.08 & 0.43 & 0.11 & $\mathrm{AD}+\mathrm{BC}$ \\
7 & 76.11 & -12.95 & 0.10 & -0.14 & $\mathrm{AC}+\mathrm{BD}$ \\
\hline & 34.03 & 20.95 & 0.24 & & \\
\hline
\end{tabular}

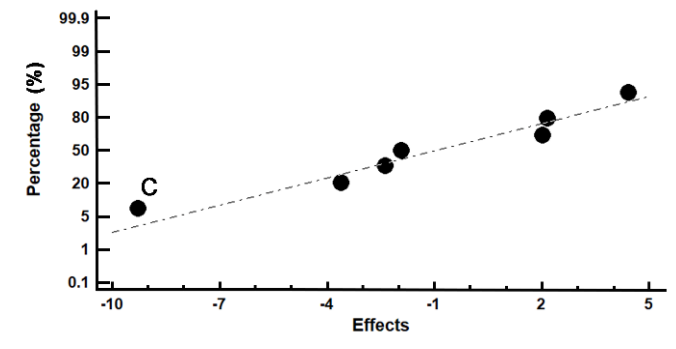

(a)

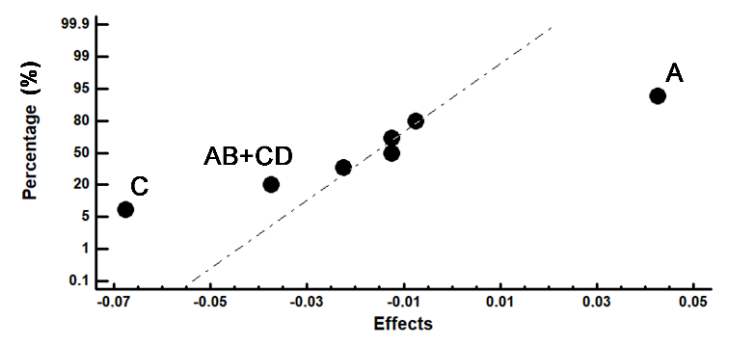

(c)

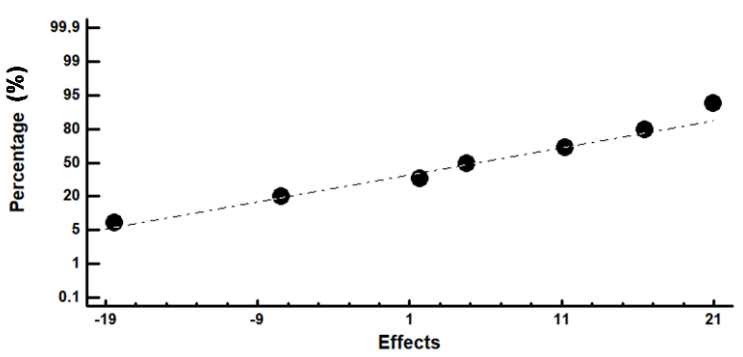

(b)

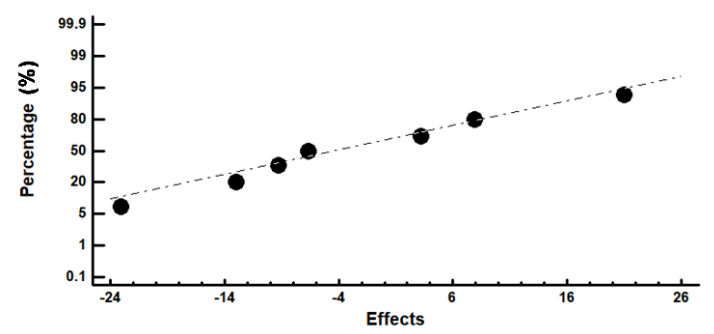

(d)

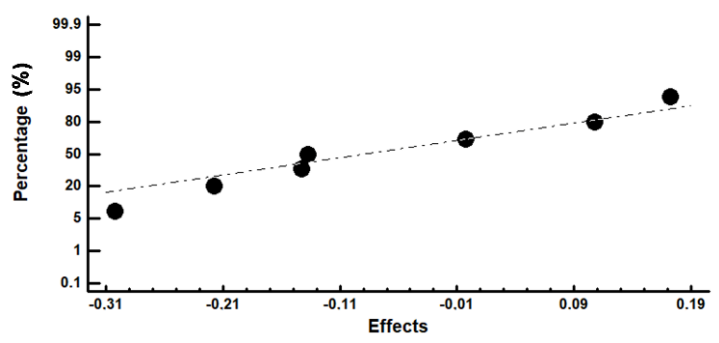

(e)

Figure 2. Representation of the standardized effects for the weight percentages of the different phases plotted on a normal probability graph. Factors with a significant effect have been labelled. A (destabilisation temperature); B (cooling media); C (tempering temperature); D (tempering time): (a) wt.\% austenite; (b) wt.\% tempered martensite; (c) cell volume of tempered martensite; (d) wt.\% carbides $\mathrm{M}_{7} \mathrm{C}_{3}\left(\mathrm{~K}_{2}\right)$; (e) wt.\% carbides $\mathrm{M}_{2} \mathrm{C}$. 
Figure 2a shows that when factor $C$ (tempering temperature) is at its -1 level $\left(400{ }^{\circ} \mathrm{C}\right)$, the percentage of retained austenite increases. Therefore, such a low ageing temperature seems insufficient for completing the transformation of residual gamma from quenching into martensite. A possible explanation may lie in the fact that a highly alloyed austenite is less prone to transformation during tempering, probably due to low $\mathrm{C}$ diffusivity at such a temperature [32]. This is because the thermal gap is lower than if tempering is carried out at $500{ }^{\circ} \mathrm{C}$. The thermal gap makes it possible to decrease free energy for the transformation of the austenite into martensite. This decrease should compensate for the increase of energy which crystalline distortion supposes due to the tetragonality of the martensite [31]. So, the more alloyed this austenite is, the greater the crystalline distortion will be and, because of this, the greater the required thermal gap must be. Figure $2 b$ shows that none of the factors have a significant effect on the weight percent of tempered martensite. However, Figure $2 \mathrm{c}$ illustrates that when factor $\mathrm{C}$ (tempering temperature) is at its -1 level $\left(400{ }^{\circ} \mathrm{C}\right)$ and factor A (destabilization temperature) is set at its +1 level $\left(1050{ }^{\circ} \mathrm{C}\right)$, an increase in the cell volume of unaged martensite follows. A possible explanation might be given by the fact that higher austenitising temperatures enable the austenite cell to admit more $C$ atoms in solid solution, and on quenching, the resulting martensite should show a more tetragonal cell [31,32]. On the other hand, this martensite would be highly alloyed, and would show a low decomposition rate on tempering because of low $\mathrm{C}$ diffusion at low tempering temperatures. Furthermore, the precipitation of chrome carbides of the type $\mathrm{M}_{7} \mathrm{C}_{3}$ does not begin until temperatures are higher than $500{ }^{\circ} \mathrm{C}$. Moreover, because of the low number of free interstitial sites in martensite effective $C$ diffusion may be restrained too. On the same plot the interaction given by $A B+C D$ has been labelled since it appears to provide a significant effect. Figure 3 presents the results of the calculations made so as to conduct the analysis of the former interactions. It can be seen that those products of $\mathrm{A} \times \mathrm{B}$ yielding a -1 value, as well as the product of $\mathrm{C} \times \mathrm{D}$ yielding also -1 value, should provide a meaningful interaction. In the first case the higher value (tallest column) corresponds to factor $A$ at its +1 level and factor $B$ to its -1 level $(+1 \times(-1)=-1)$. For the CD interaction, the highest value corresponds to factor $C$ at its -1 level, and factor $\mathrm{D}$ at its $+1(-1 \times(+1)=-1)$. Comparing both interactions, the most representative, i.e., the one with the highest value is the interaction CD: factor $C$ (tempering temperature) at its -1 level $\left(400^{\circ} \mathrm{C}\right)$ and factor $\mathrm{D}$ at its +1 level $(6 \mathrm{~h})$. The value found for the cell volume of martensite when $\mathrm{D}$ factor is at its -1 level $\left(550^{\circ} \mathrm{C}\right)$ provides a somewhat similar value for the cell volume of unaged martensite, thus limiting the effect of factor $D$ in the interaction given by CD. In summary, what seems relevant to obtaining a high-volume cell of martensite after tempering is the use of low tempering temperature, making the dwell time at tempering less relevant when it is comprised of between 2 and $6 \mathrm{~h}$.

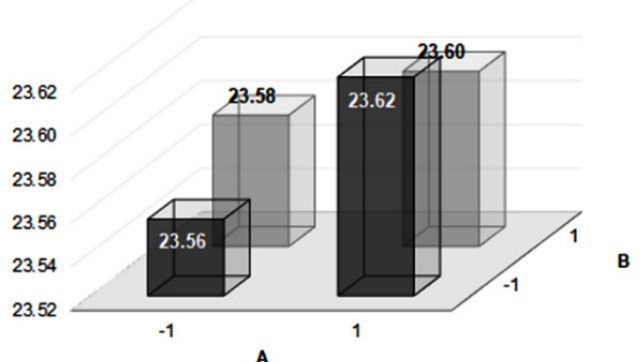

(a)

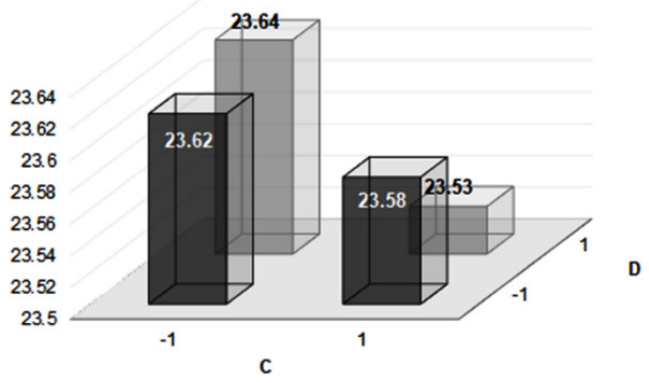

(b)

Figure 3. Analysis of interactions with a significant effect with respect to the cell volume of unaged martensite. X-axis represents the two levels of A-factor (figure (a)) and the two levels of C-factor (figure (b)). Y-axis represents the two levels of B-factor (figure (a)) and the two levels of D-factor (figure (b)). Z-axis represents the effect of each possible combination of the factors: (a) interaction $\mathrm{AB}$; (b) interaction $\mathrm{CD}$. 
Table 6 shows the loss of material (in mg.) during the wear test of the specimens against a rubber wheel with ungrounded dry silica sand acting as an abrasive interface. It also shows the corresponding standardised effects and their correspondence with the confounding patterns.

Table 6. Loss of material (mg.) after $30 \mathrm{~min}$ of a continuous abrasive wear test conducted in accordance with the ASTM G40-92 standard.

\begin{tabular}{ccccc}
\hline \multirow{2}{*}{$\begin{array}{c}\text { Experiment } \\
\text { Number }\end{array}$} & \multicolumn{3}{c}{ Wear Loss (30 min) } & Confounding \\
\cline { 2 - 3 } & $\mathbf{m g}$ & CL (95\%) & Effects & \\
\hline 1 & 97.08 & \pm 0.75 & 130.02 & Average \\
2 & 120.30 & \pm 1.45 & -29.415 & $\mathrm{~A}$ \\
3 & 92.35 & \pm 2.10 & 3.03 & $\mathrm{~B}$ \\
4 & 113.00 & \pm 0.20 & 48.675 & $\mathrm{C}$ \\
5 & 194.33 & \pm 1.47 & 6.27 & $\mathrm{D}$ \\
6 & 102.31 & \pm 1.75 & 4.985 & $\mathrm{AB}+\mathrm{CD}$ \\
7 & 195.15 & \pm 0.37 & -51.35 & $\mathrm{AC}+\mathrm{BD}$ \\
8 & 125.64 & \pm 1.16 & 9.045 & $\mathrm{AD}+\mathrm{BC}$ \\
\hline
\end{tabular}

Figure 4 shows the main factors which have a significant effect with respect to an increase in the abrasive wear rate measured by the loss of weight of samples for each experiment. Such factors are: Factor A (temperature of destabilisation of austenite) at its -1 level $\left(950^{\circ} \mathrm{C}\right)$, and factor $\mathrm{C}$ (tempering temperature) at its +1 level $\left(550^{\circ} \mathrm{C}\right)$, increase the wear rate. Conversely, a destabilisation treatment of austenite at $1050{ }^{\circ} \mathrm{C}$ and a tempering treatment at $400{ }^{\circ} \mathrm{C}$ increase the resistance to abrasive wear. The result is in agreement with the factors which also increase the hardness of the matrix constituent, as will be shown later. The results obtained in this manner could be explained by the higher volume fraction of secondary carbides formed in the matrix constituent at a high destabilisation temperature, as well as by the presence of unaged martensite at low tempering temperatures $[26,35]$.

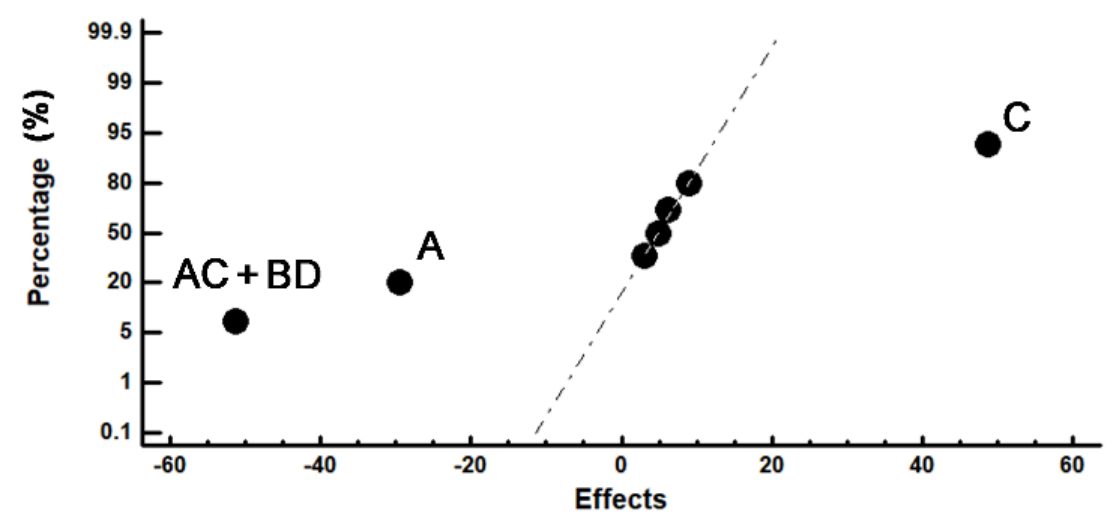

Figure 4. Representation of the standardized effects on the weight loss by abrasive wear in a test of 30 min duration, plotted on a normal probability graph. A (destabilisation temperature); B (cooling media); C (tempering temperature); D (tempering time).

The significant effect of the interactions $\mathrm{AC}$ and BD are also shown in Figure 5. The result of the analysis is depicted in the block diagram in Figure 5. It can also be observed how the combination of factors $\mathrm{A}$ and $\mathrm{C}$, at their respective -1 and +1 levels (destabilisation of the austenite at $950{ }^{\circ} \mathrm{C}$ and tempering at $550{ }^{\circ} \mathrm{C}$ ), lead to an increase in the wear rate. Thus, this combination yields a more deleterious behaviour for abrasive wear resistance when those main factors operate at those levels than when they are selected individually. These suggest a synergic interrelation of these factors and corresponding levels. 


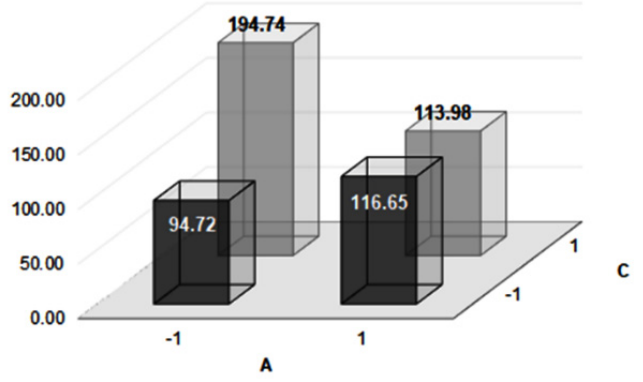

(a)

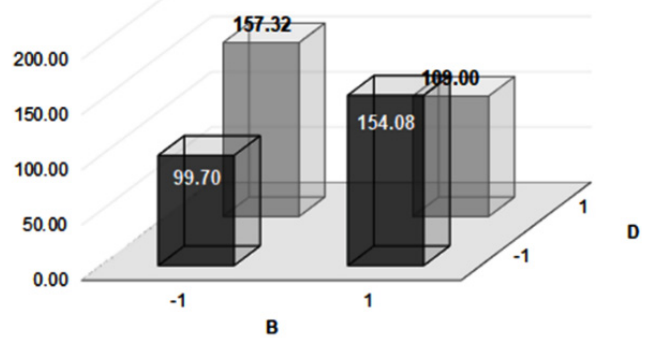

(b)

Figure 5. Analysis of interactions with significant effects with respect to abrasive wear. X-axis represents the two levels of A-factor (figure (a)) and the two levels of B-factor (figure (b)). Y-axis represents the two levels of C-factor (figure (a)) and the two levels of D-factor (figure (b)). Z-axis represents the effect of each possible combination: (a) interaction AC; (b) interaction BD.

Figure 6 shows SEI (Secondary Electron Image) SEM micrographs of the wear surface in experiments 1 and 3 once the abrasive test was concluded. Scratches may be observed on the surface of the $\mathrm{K}_{2}$ eutectic carbides which are less evident on the matrix, suggesting different mechanisms of degradation for both of them. $\mathrm{K}_{2}$ eutectic carbides, with $\mathrm{HV}$ values in the range of 1500-1800 have been lightly scratched by AFS 50/70 ungrounded silica sand which has a lower hardness, but should these carbides become repeatedly abraded, shallow grooves would form. The wear mechanism in the matrix shows uniform wear with occasional tearing and decohesion between carbides and matrix constituents. It is possible to distinguish what seems to be occasional detachment of small broken pieces of $\mathrm{K}_{2}$ carbides, leaving a hole in the matrix after particle release.

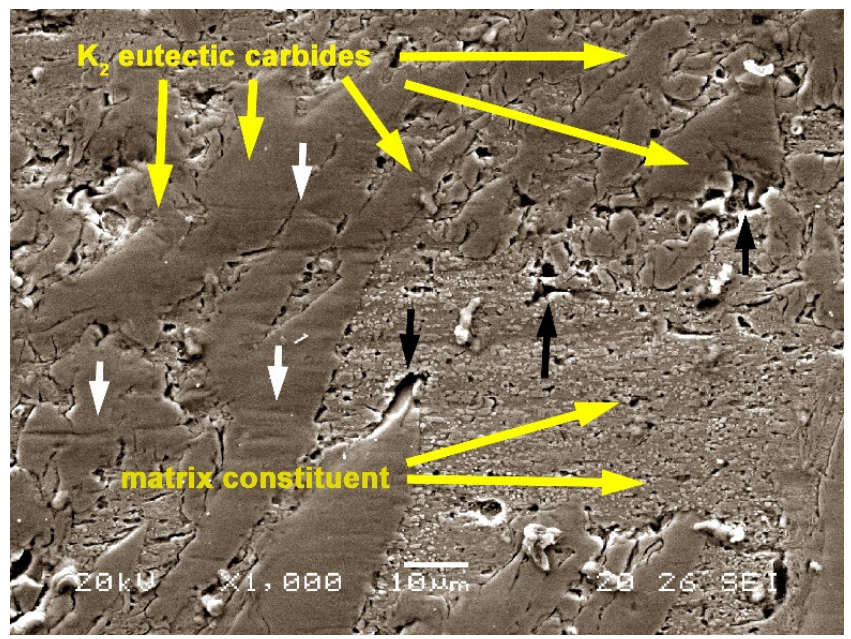

(a)

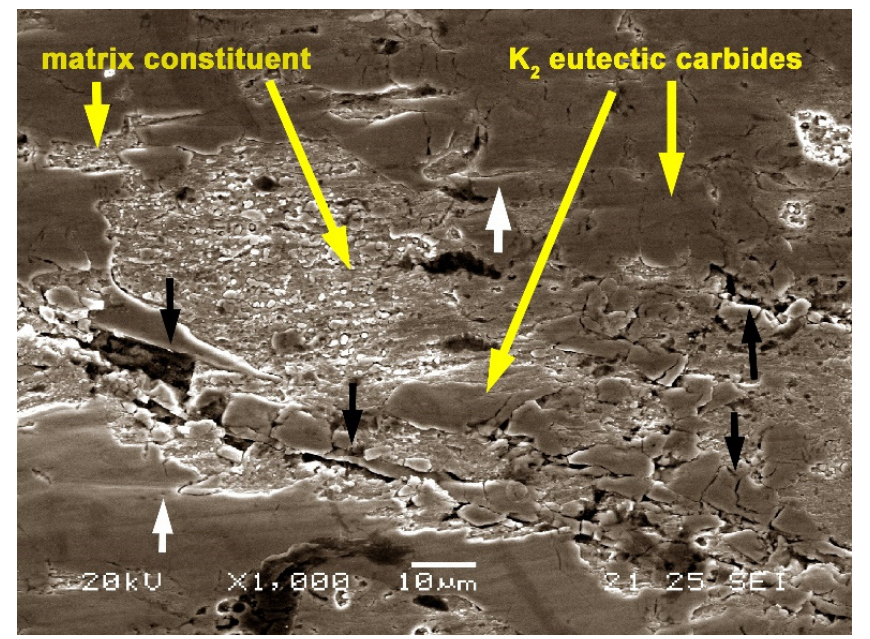

(b)

Figure 6. Abrasive wear surface in Scanning Electron Microscope (SEM) (a) experiment 1; (b) experiment 3. Black arrows show the areas of decohesion of broken eutectic carbides from the matrix constituent. White arrows show shallow scratches on the surface of bulk $\mathrm{K}_{2}$ eutectic carbides [36,37].

Table 7 shows the average values and the standardised effects obtained for the microhardness of the matrix constituent as well as the normalised energy absorbed in the fracture of unnotched cylindrical specimens obtained after impact testing in a Hounsfield balanced machine. Figure 7 show the standardised effects for the matrix microhardness. Once represented on normal probability graphs, and those factors with significant effects were correspondingly labelled. 
Table 7. Average values and standardised effects obtained for the microhardness of the matrix constituent and the impact toughness measured in a Hounsfield balanced impact machine.

\begin{tabular}{cccccccc}
\hline \multirow{2}{*}{$\begin{array}{c}\text { Experiment } \\
\text { Number }\end{array}$} & \multicolumn{3}{c}{ Microhardness } & \multicolumn{3}{c}{ Impact Toughness } & \multirow{2}{*}{$\begin{array}{c}\text { Confounding } \\
\text { Pattern }\end{array}$} \\
\cline { 2 - 6 } & HV & CL (95\%) & Effect & J/cm & CL (95\%) & Effect & Average \\
\hline 1 & 732 & \pm 15 & 667.0 & 8.85 & \pm 1 & 6.8 & $\mathrm{~A}$ \\
2 & 764 & \pm 17 & 129.2 & 3.12 & \pm 0.27 & -1.8 & $\mathrm{~B}$ \\
3 & 664 & \pm 30 & -51.2 & 1.66 & \pm 0.18 & 0.5 & $\mathrm{C}$ \\
4 & 756 & \pm 23 & -123.2 & 4.73 & \pm 0.5 & 4.4 & $\mathrm{D}$ \\
5 & 527 & \pm 7 & -27.7 & 10.41 & \pm 1.5 & 0.0 & $\mathrm{AB}+\mathrm{CD}$ \\
6 & 749 & \pm 20 & 2.2 & 3.79 & \pm 0.4 & 4.4 & $\mathrm{AD}+\mathrm{BC}$ \\
7 & 488 & \pm 14 & 67.2 & 9.89 & \pm 1 & -0.5 & $\mathrm{AC}+\mathrm{BD}$ \\
\hline
\end{tabular}

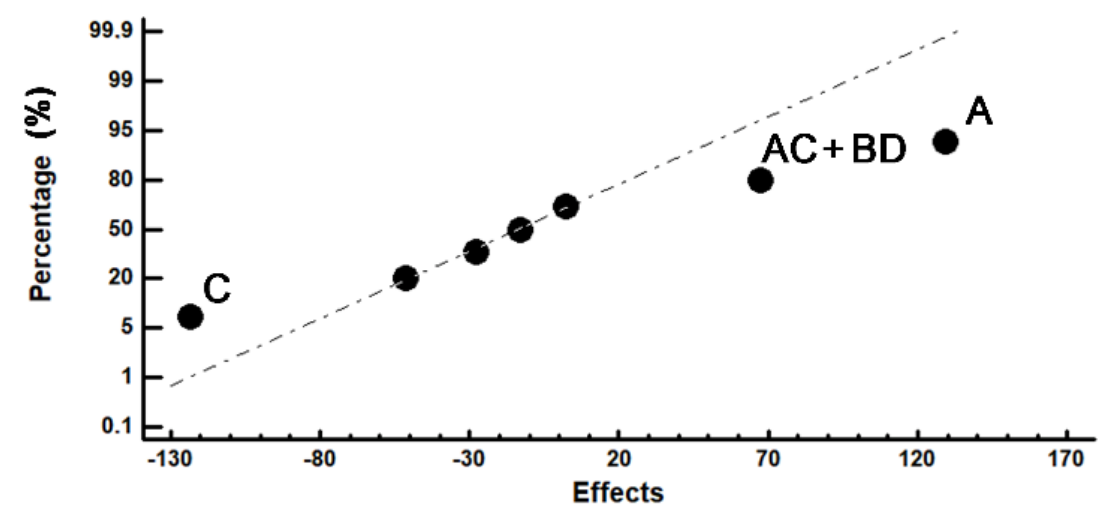

Figure 7. Representation of the factors with significant effect on the hardness of the matrix constituent on a normal probability graph. A (destabilisation temperature); B (cooling media); C (tempering temperature); D (tempering time).

In Figure 7 it can be seen that the hardness of the matrix constituent increases when factor A (temperature of destabilisation) is at its +1 level $\left(1050^{\circ} \mathrm{C}\right)$, and factor $\mathrm{C}$ (tempering temperature) is at its -1 level $\left(450{ }^{\circ} \mathrm{C}\right)$. At high temperatures of destabilisation and a sufficient dwell time at temperature, supersaturated austenite from quenching starts gaining equilibrium by precipitating alloy carbides from the excess of $\mathrm{C}$ and $\mathrm{Cr}$ in the $\gamma$ cells. At a lower rate, non-equilibrium eutectic, formed at high solidification rates typical of industrial practice, gradually disappears as it approaches equilibrium. As a result of this microstructural change, a new high maximum solubility of carbon for austenite is reached, which, on quenching, yields a more slender tetragonal martensite cell, which the X-ray diffraction analyses have confirmed. This, along with a low tempering temperature could be insufficient for alloyed martensite to age during tempering, and this is thought to entail an increase in the hardness of the matrix phase [31,32].

A sum of interactions $\mathrm{AC}+\mathrm{BD}$, with a significant effect in the matrix microhardness, can also be observed in Figure 7. The detailed analysis of the interaction of the effects is presented in Figure 8a, which shows that for the interaction AC, with factor A at its +1 level and factor $C$ at its -1 level, shows more prominent results than the rest. However, such levels yield a negative value for the interaction itself: $\mathrm{A} \times \mathrm{C} \propto(+1$ level $)$ $\times(-1$ level $)=-1$. Such an interaction AC, in order to be considered correct, should have appeared to the left and at the low end of the straight line in the normal probability plot in Figure 7, and thus, it explains why such interaction is dismissed. In summary, each separate factor has a significant effect on the increase in the matrix hardness but, if the two factors perform together at the levels dictated by the interaction no significant effect is appreciated. Figure $8 \mathrm{~b}$ also shows the interaction BD to have a significant effect when both factors are at level -1 , that is to say, when the cooling rate is slower (in a current of hot air at $\left.150{ }^{\circ} \mathrm{C}\right)$, and the time of tempering is shorter $(2 \mathrm{~h})$. This could be interpreted 
as the possibility of further precipitation of $\mathrm{K} 2$ carbides between 400 and $600{ }^{\circ} \mathrm{C}$ at slow cooling rates, and thus its contribution to the structural hardening of austenite, as has been reported by these authors in an earlier work [26]. Regarding the role of tempering for shorter times and its contribution to the increase in hardness of the matrix, it is thought that such an increase could perhaps be attributed to the presence of unaged hard martensite after treatment.

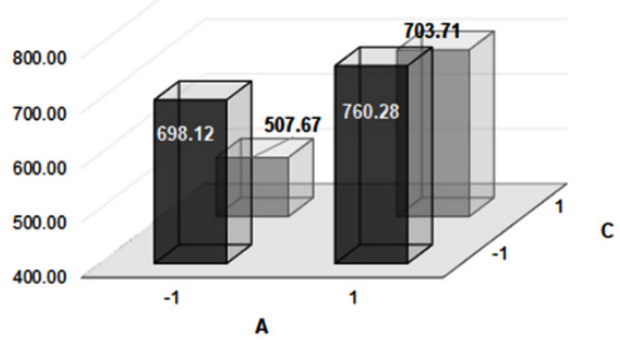

(a)

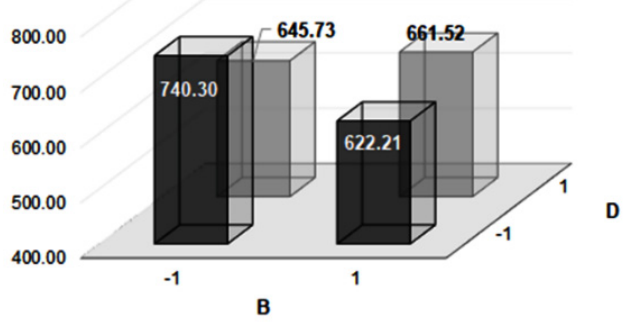

(b)

Figure 8. Analysis of interactions with a significant effect with respect to the hardness of the constituent matrix. X-axis represents the two levels of A-factor (figure (a)) and the two levels of B-factor (figure (b)). Y-axis represents the two levels of C-factor (figure (a)) and the two levels of D-factor (figure (b)). Z-axis represents the effect of each possible combination: (a) interaction $\mathrm{AC} ;(\mathbf{b})$ interaction $\mathrm{BD}$.

Figure 9 shows selected SEM micrographs for experiments 4 and 5, chosen because of great differences in the matrix constituent hardness. In the micrograph corresponding to experiment 4 the abundant presence of retained austenite is highlighted. This can be distinguished from the $\mathrm{M}_{7} \mathrm{C}_{3}$ carbides since these have a rounded morphology and a slightly darker colouring. The material corresponding to experiment 4 resulted in greater hardness of the matrix constituent along with a greater resistance to abrasive wear. On the other hand, the material corresponding to experiment 5 gave lower values for identical responses, as shown in the results of Tables 6 and 7. Experiment 4 with high matrix hardness and high wear resistance, corresponded to a specimen being tempered at $550{ }^{\circ} \mathrm{C}$ for $6 \mathrm{~h}$. It seems that this specific ageing at high temperature and for a long time could have favoured structural hardening by partial ageing of retained austenite from quenching. Moreover, the tempering of martensite at $550{ }^{\circ} \mathrm{C}$ could have contributed to structural hardening through the precipitation of $\mathrm{M}_{7} \mathrm{C}_{3}$ carbides. It can be observed how the matrix constituent in experiment 4 presents a lower density of carbides compared to the matrix constituent in experiment 5 .

Figure 10 shows the effects on the toughness of the material, characterised with the Hounsfield test, represented on a normal probability plot. Factor C (tempering temperature) is significant at its +1 level $\left(550{ }^{\circ} \mathrm{C}\right)$. Moreover, the effects of the interactions $\mathrm{AB}+\mathrm{CD}$ and $\mathrm{AD}+\mathrm{BC}$ are significant when the product of their respective levels yield $\mathrm{a}+1$. These interactions are analysed in Figure 11. It is concluded that the higher toughness is obtained when Factor B stands at its +1 level (oil quenching) thus maximizing the volume fraction of martensite ensuring a minimal fraction of austenite. Moreover, when both Factor $\mathrm{C}$ (tempering temperature) and Factor D, both standing at their +1 level $\left(550{ }^{\circ} \mathrm{C}\right.$ and $6 \mathrm{~h}$ dwell respectively). In conclusion, the way to gain a good impact response would be by firstly ensuring the maximum conversion of austenite into martensite on quenching, which would be obtained with high severity media: oil at RT with very gentle stirring, preferable to stirred hot air at $150{ }^{\circ} \mathrm{C}$. Highly alloyed austenite usually requires two tempering treatments to age, unlike martensite which tempers with just one, on condition that the temperature and time are high enough $\left(550{ }^{\circ} \mathrm{C}\right.$ and $\left.6 \mathrm{~h}\right)$ to promote diffusion and the possibility of reaching the solubility product to allow the formation of high temperature alloyed carbides. 


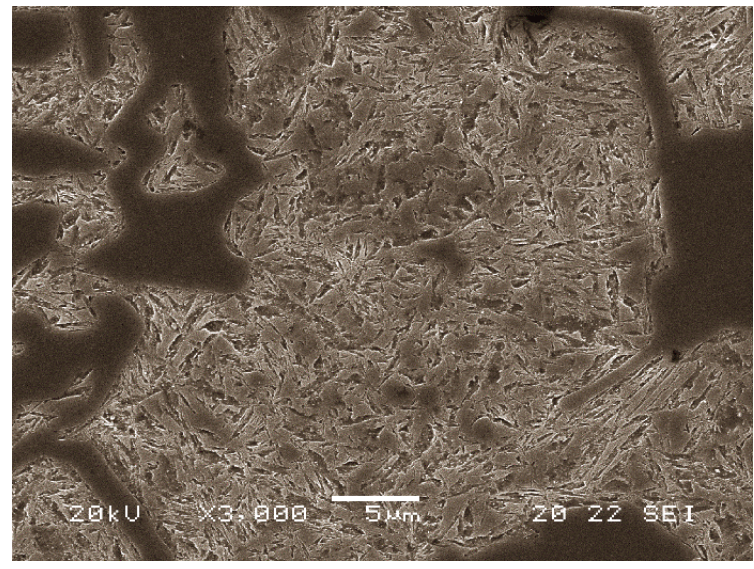

(a)

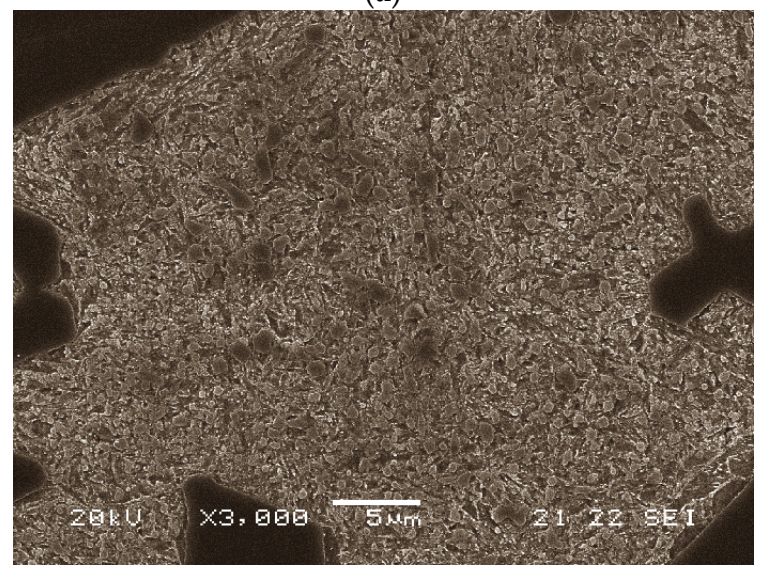

(c)

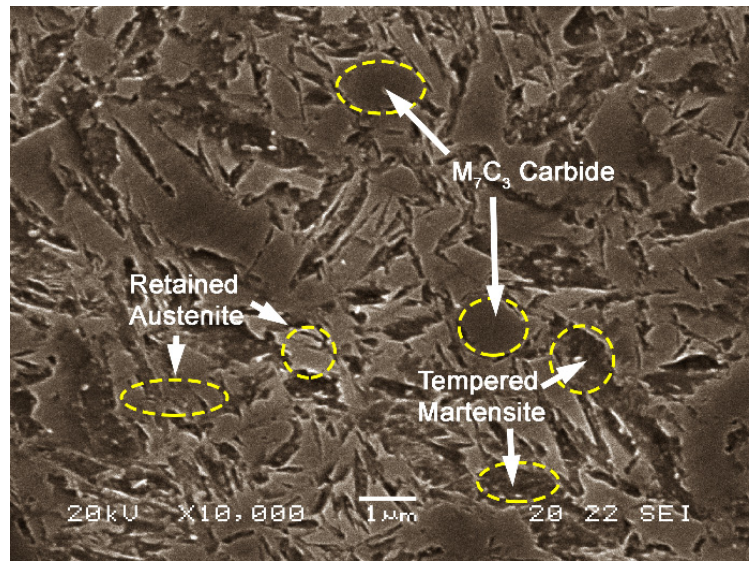

(b)

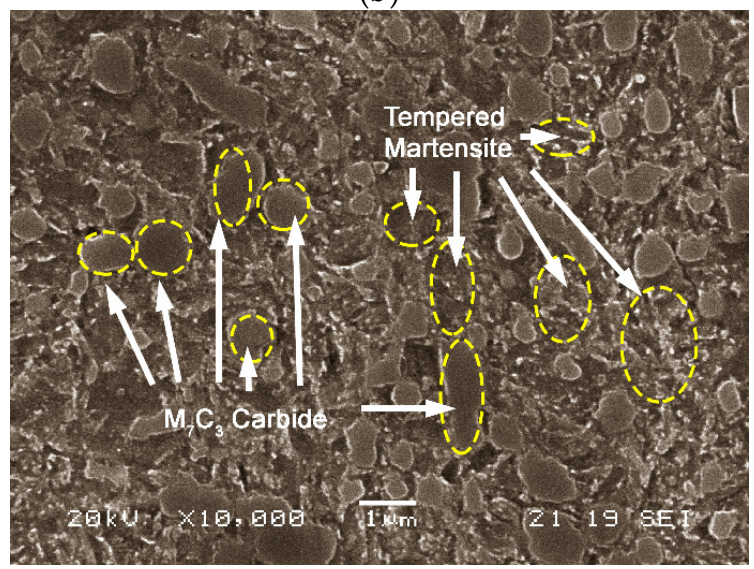

(d)

Figure 9. Selected SEM micrographs for experiments 4 and 5 . (a,b) correspond to experiment 4 ; (c,d) correspond to experiment 5 .

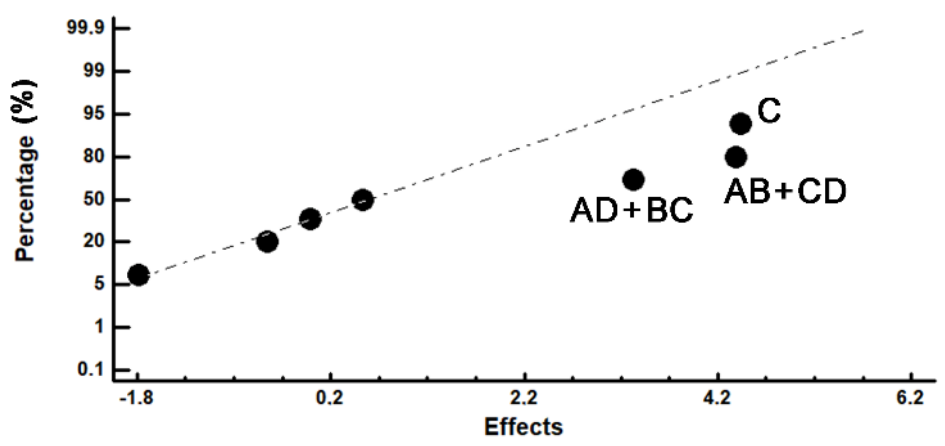

Figure 10. Representation on a normal probability plot of the factors with a significant effect on the response to impact. A (destabilisation temperature); B (cooling media); C (tempering temperature); $\mathrm{D}$ (tempering time).

Experiment 8 showed the value for highest energy absorbed, and with regard to the factors with significant effect in the improvement of impact toughness, this experiment corresponds to a high destabilisation temperature. An increase in the temperature prior to quenching ensures a depleted austenite in alloy elements because of the intrinsic nature of destabilisation, consisting of the formation of alloy carbides. This leads to a higher Ms and Mf temperatures and thus, a higher volume fraction of martensite formed. Figure 12 shows the microstructure of this experiment which corresponds to austenitising at $1050{ }^{\circ} \mathrm{C}$ for $5 \mathrm{~h}$, followed by oil cooling and tempering at $550{ }^{\circ} \mathrm{C}$ for $6 \mathrm{~h}$. Its matrix constituent does not show the presence of austenite but illustrates an elevated density of carbides. 


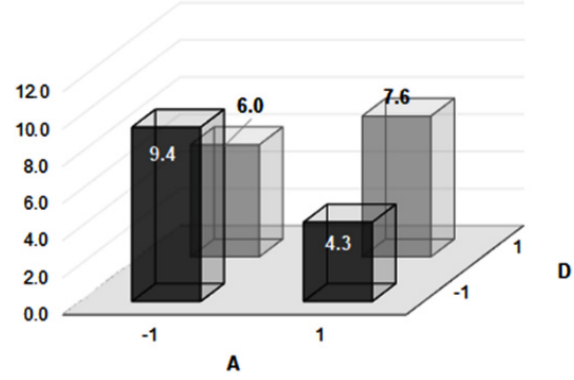

(a)

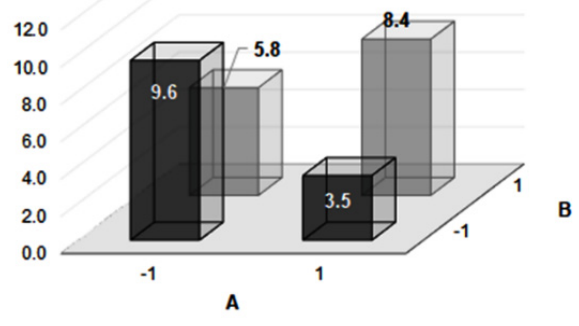

(c)

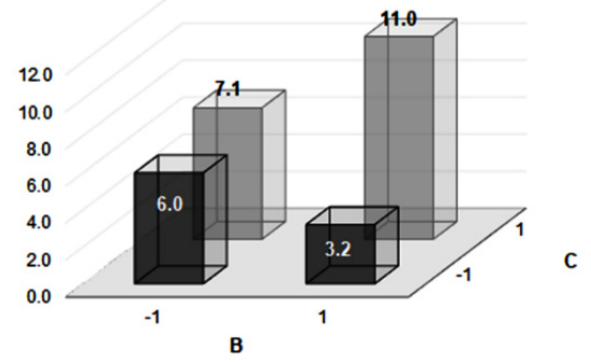

(b)

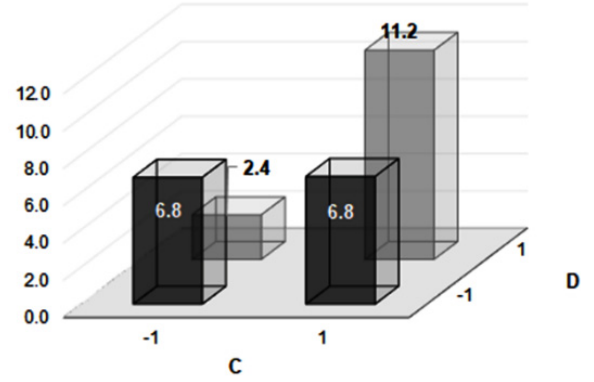

(d)

Figure 11. Analysis of the interactions with a significant effect on toughness of material, characterised with the Hounsfield test. X-axis represents the two levels of A-factor (figure (a)), of B-factor (figure (b)), of A-factor (figure (c)), and C-factor (figure (d)). Y-axis represents the two levels of D-factor (figure (a)) of C-factor (figure (b)), of B-factor (figure (c)), of D-factor (figure (d)). Z-axis represents the effect of each possible combination: (a) interaction AB; (b) interaction CD; (c) interaction $\mathrm{AD} ;(\mathbf{d})$ interaction $\mathrm{BC}$.
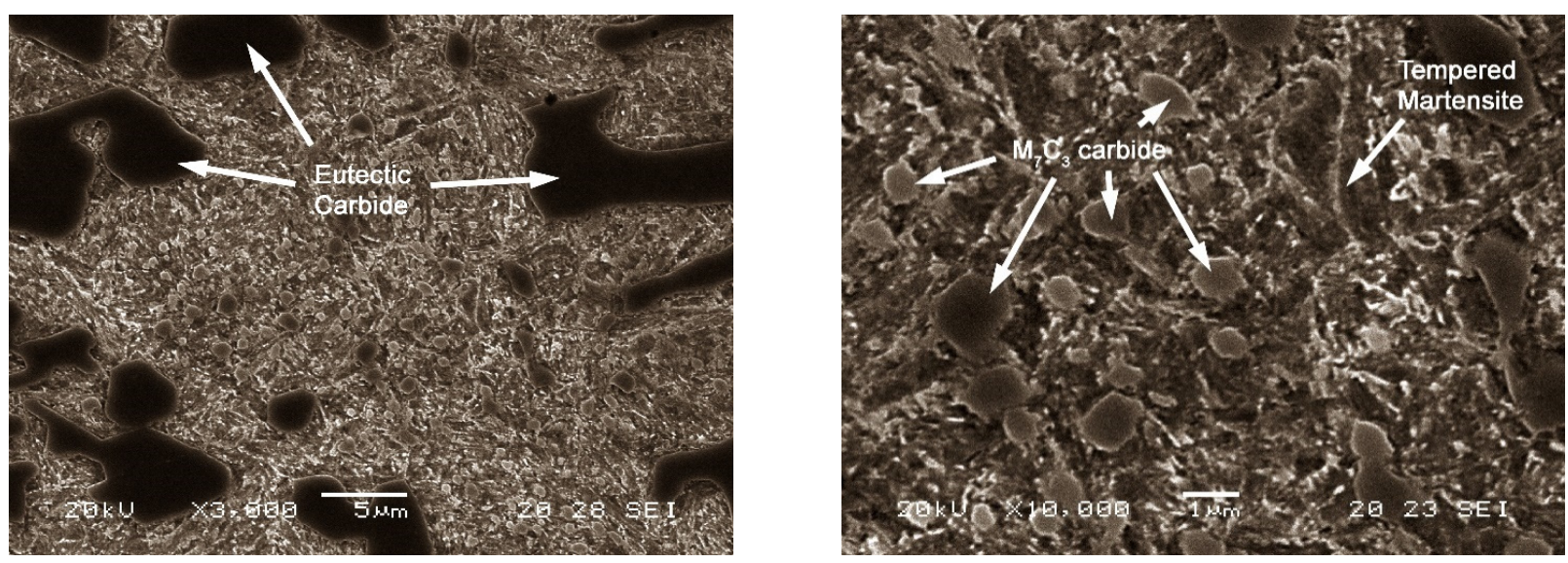

Figure 12. Microstructure corresponding to experiment 8 . A high density of carbides in the matrix can be observed.

With regard to the values in Table 4 , the presence of carbides of the $\mathrm{M}_{2} \mathrm{C}$ type, associated with Mo is confirmed for Table 8 . Figure 13 shows a BEI image confirming the presence of this carbide with skeletal morphology which is nucleated from the eutectic $M_{7} C_{3}$ [38].

Table 8. Semi-quantitative analysis of phases shown in Figure 13a,b. This analysis was carried out through an energy dispersive X-ray microanalysis (EDX). (\% atomic).

\begin{tabular}{ccccc}
\hline Spectrum & C & Cr & Fe & Mo \\
\hline 1 & 45.24 & 4.88 & 23.70 & 26.18 \\
2 & 34.27 & 39.12 & 26.61 & - \\
3 & 40.62 & 11.51 & 24.18 & 23.69 \\
4 & 31.56 & 40.43 & 28.01 & - \\
\hline
\end{tabular}




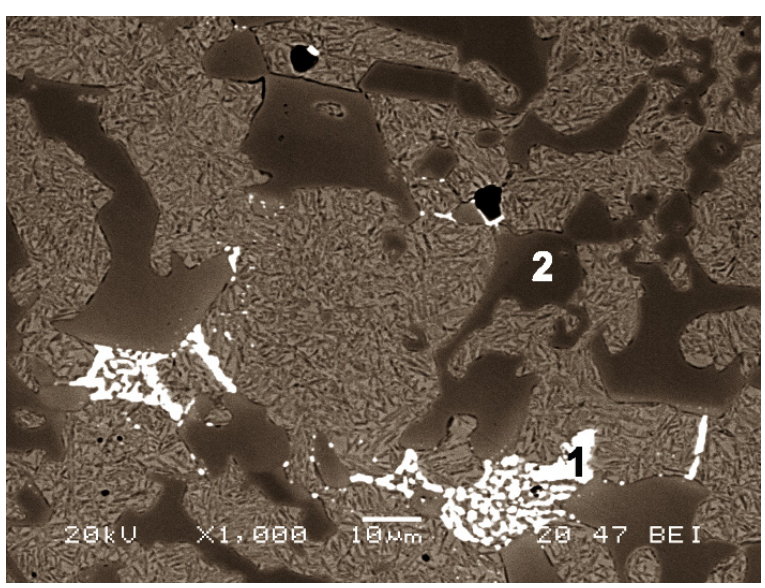

(a)

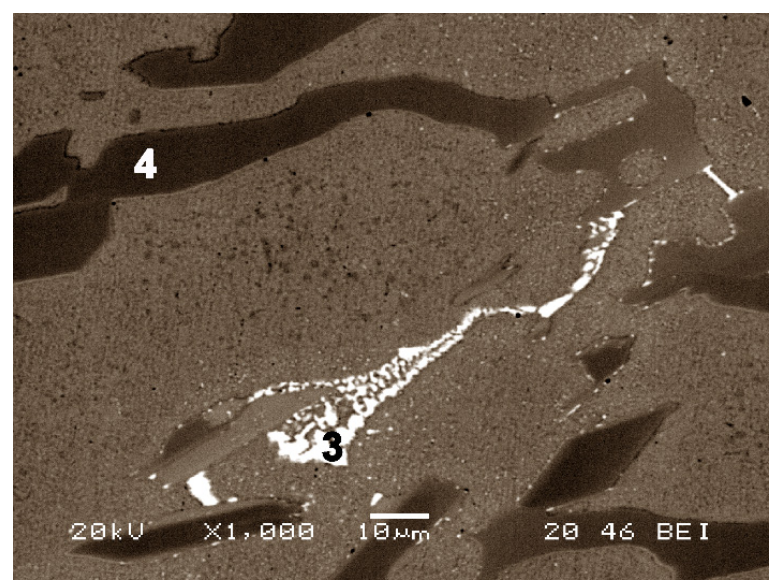

(b)

Figure 13. Presence of carbides $\mathrm{M}_{2} \mathrm{C}$, associated with Mo. The numbers 1-4 correspond to the spectra in Table 8: (a) experiment 2; (b) experiment 7 . Images obtained in a back scattered electron detector.

\section{Conclusions}

The application of Fractional Factorial Design of Experiments with minimum fractioning has allowed the analysis of the effect of four metallurgical factors at two fixed levels to assess both microstructural features and selected mechanical properties in just eight experiments. The factors and their levels are related to the heat treatments to apply to as-cast components made in high chromium cast irons prior to commissioning. These factors are: the destabilisation of austenite for $5 \mathrm{~h}$ at two temperatures $\left(950{ }^{\circ} \mathrm{C}\right.$ or $\left.1050{ }^{\circ} \mathrm{C}\right)$, the quenching media (agitated air at $150{ }^{\circ} \mathrm{C}$ or oil gently stirred at $20^{\circ} \mathrm{C}$ ); and finally, the tempering temperature $\left(400\right.$ and $\left.500{ }^{\circ} \mathrm{C}\right)$ at two dwell times $(2 \mathrm{~h}$ and $6 \mathrm{~h})$, the latter with the purpose of increasing abrasive wear resistance while modestly improving its impact toughness to fracture. A summary of the findings of this experimental work follows below.

To increase the resistance to abrasive wear the following is recommended:

1. The use of high destabilisation temperatures, around $1050^{\circ} \mathrm{C}$, followed by cooling in hot air at $150{ }^{\circ} \mathrm{C}$. Destabilisation at $1050{ }^{\circ} \mathrm{C}$ allows secondary $\mathrm{M}_{7} \mathrm{C}_{3}$ carbide precipitation from supersaturated austenite accompanied by partial solubilisation of non-equilibrium eutectic carbides which form during solidification. The after cooling that follows if taking place within an air convection furnace set at $150{ }^{\circ} \mathrm{C}$, seemed to favour further carbide formation in the range of $400-600{ }^{\circ} \mathrm{C}$.

2. Abrasion resistance is also favoured by low tempering temperatures $\left(400{ }^{\circ} \mathrm{C}\right)$ and shorter tempering times $(2 \mathrm{~h})$. They both seem to favour a fine and dispersed precipitation. From X-ray diffraction analysis, the tempering conditions seemed insufficient for complete ageing of martensite as has been shown by the lattice results which indicate the existence of slender tetragonal lattice remaining after treatment. Thus, its possible contribution to the matrix hardness.

To increase the dynamic impact energy absorbed the following is advised:

1. Quenching in gently stirred oil at ambient temperature has been checked to promote full conversion of destabilised austenite into martensite i.e., to favour the absence of retained austenite after quench. This retained austenite is found to be highly alloyed and with accumulated plastic deformation due to the adjacent presence of tetragonal martensite, thus the need for the absence of residual austenite for better impact response.

2. Tempering at $550{ }^{\circ} \mathrm{C}$ and long dwell tempering times of around $6 \mathrm{~h}$, helped to complete full ageing of martensite thus the increase of overall toughness. 
Author Contributions: J.A.-L. Conceived and designed the investigation; A.G.-P. and A.G.-D. Performed all laboratory work; F.Á.-A. led the investigation, analysed the data and wrote the paper. All authors have read and agreed to the published version of the manuscript.

Funding: This research received no external funding.

Data Availability Statement: Data is contained within the article.

Conflicts of Interest: The authors declare no conflict of interest.

\section{References}

1. Standard Specification for Abrasion-Resistant Cast Irons; A532/A532M-10; ASM International: West Conshohocken, PA, USA, 2019. [CrossRef]

2. Amorim, P.; Santos, H.; Santos, J.; Coimbra, S.; Sá, C. Soft Annealing of High Chromium White Cast Iron. Mater. Sci. Forum 2004, 455-456, 290-294. [CrossRef]

3. Abdel-Aziz, K.; El-Shennawy, M.; Omar, A.A. Microstructural characteristics and mechanical properties of heat treated high-cr white cast iron alloys. Int. J. Appl. Eng. Res. 2017, 12, 4675-4686.

4. Nayak, U.P.; Guitar, M.A.; Mücklich, F. A comparative study on the influence of chromium on the phase fraction and elemental distribution in as-cast high chromium cast irons: Simulation vs. experimentation. Metals 2020, 10, 30. [CrossRef]

5. Jones, M.; Llewellyn, R.J. Erosion-corrosion assessment of materials for use in the resources industry. Wear 2009, 267, 2003-2009. [CrossRef]

6. Llewellyn, R.J.; Yick, S.K.; Dolman, K.F. Scouring erosion resistance of metallic materials used in slurry pump service. Wear 2004, 256, 592-599. [CrossRef]

7. Zhang, J.-C.; Zhang, T.; Yang, Y.T. Microstructure and properties evolution of Nb-bearing medium Cr wear-resistant cast steel during heat treatment. J. Iron Steel Res. Int. 2020. [CrossRef]

8. Poolthong, N.; Nomura, H.; Takita, M. Effect of heat treatment on microstructure and properties of semi-solid chromium cast iron. Mater. Trans. 2004, 45, 880-887. [CrossRef]

9. Karantzalis, A.E.; Lekatou, A.; Mavros, H. Microstructural Modifications of As-Cast High-Chromium White Iron by Heat Treatment. J. Mater. Eng. Perform. 2009, 18, 174-181. [CrossRef]

10. Pero-Sanz, J.A. Fundiciones Férreas; Dossat: Madrid, Spain, 1994; pp. 123, 129.

11. Tang, X.H.; Chung, R.; Li, D.Y.; Hinckley, B.; Dolman, K. Variations in microstructure of high chromium cast irons and resultant changes in resistance to wear, corrosion and corrosive wear. Wear 2009, 267, 116-121. [CrossRef]

12. Hanlon, D.N.; Rainforth, W.M.; Sellars, C.M. The rolling/sliding wear response of conventionally processed and spray formed high chromium content cast iron at ambient and elevated temperature. Wear 1999, 225-229, 587-599. [CrossRef]

13. Kopyciński, D.; Guzik, E.; Szczęsny, A. Equiaxed and oriented microstructure in high chromium cast iron. Arch. Metall. Mater. 2014, 59, 723-726. [CrossRef]

14. Walker, C.I.; Hambe, M. Influence of particle shape on slurry wear of white iron. Wear 2015, 332-333, 1021-1027. [CrossRef]

15. Doğan, Ö.N.; Hawk, J.A. Effect of carbide orientation on abrasion of high Cr white cast iron. Wear 1995, 189, 136-142. [CrossRef]

16. Zum Gahr, K.H.; Eldis, G.T. Abrasive wear of white cast irons. Wear 1980, 64, 175-194. [CrossRef]

17. Thorpe, W.R.; Chicco, B. The Fe-rich corner of the metastable C-Cr-Fe liquidus surface. Metall. Trans. A 1985, 16, 1541-1549. [CrossRef]

18. Kadhim, M.J.; Abood, A.N.; Yaseen, R.S. The role of manganese on microstructure of high chromium white cast iron. Mod. Appl. Sci. 2011, 5, 179-185. [CrossRef]

19. Pearce, J.T.H. The use of transmission electron microscopy to study the effects of abrasive wear on the matrix structure of a high chromium cast iron. Wear 1983, 89, 333-344. [CrossRef]

20. Sinatora, A.; Pohl, M.; Waldherr, E.U. Wear induced martensite in high chromium cast iron. Scr. Metall. Mater. 1995, 32, 857-861. [CrossRef]

21. Zhang, M.X.; Kelly, P.M.; Gates, J.D. The effect of heat treatment on the toughness, hardness and microstructure of low carbon white cast irons. J. Mater. Sci. 2001, 36, 3865-3875. [CrossRef]

22. Davis, J.R. Metallurgy and properties of high alloy white irons. ASM Specially Hand Book, Cast Irons; ASM International: Materials Park, OH, USA, 1996; pp. 107-130.

23. Chung, R.J.; Tang, X.; Li, D.Y.; Hinckley, B.; Dolman, K. Microstructure refinement of hypereutectic high Cr cast irons using hard carbide-forming elements for improved wear resistance. Wear 2013, 301, 695-706. [CrossRef]

24. Karantzalis, A.E.; Lekatou, A.; Diavati, E. Effect of destabilization heat treatments on the microstructure of high-chromium cast iron: A microscopy examination approach. J. Mater. Eng. Perform. 2009, 18, 1078-1085. [CrossRef]

25. Tabrett, C.P.; Sare, I.R. Fracture toughness of high-chromium white irons: Influence of cast structure. J. Mater. Sci. 2000, 35, 2069-2077. [CrossRef]

26. Gonzalez-Pociño, A.; Alvarez-Antolin, F.; Asensio-Lozano, J. Erosive wear resistance regarding different destabilization heat treatments of austenite in high chromium white cast iron, alloyed with Mo. Metals 2019, 9, 522. [CrossRef] 
27. Powell, G. Improved Wear-Resistant High-Alloyed White Irons-a Historical Perspective. In Proceedings of the International Congress on Abrasion Wear Resistance Alloyed White Cast Iron for Rolling and Pulverizing Mills, Fukuoka, Japan, 16-20 August 2002; pp. 1-10.

28. Wang, J.; Li, C.; Liu, H.; Yang, H.; Shen, B.; Gao, S.; Huang, S. The precipitation and transformation of secondary carbides in a high chromium cast iron. Mater. Charact. 2006, 56, 73-78. [CrossRef]

29. Oanh, N.T.H.; Viet, N.H. Precipitation of M23C6 secondary carbide particles in Fe-Cr-Mn-C alloy during heat treatment process. Metals 2020, 10, 157. [CrossRef]

30. Tabrett, C.P.; Sare, I.R.; Ghomashchi, M.R. Microstructure-property relationships in high chromium white iron alloys. Int. Mater. Rev. 2014, 41, 59-82. [CrossRef]

31. Pero-Sanz, J.A. Aceros. Metalurgia Física, Selección y Diseño; Dossat: Madrid, Spain, 2004; pp. 70-71, 128-142.

32. Bhadeshia, H.K.D.H.; Honeycombe, R.W.K. Steels: Microstructure and Properties; Butterworth-Heinemann (Elsevier): London, UK, 2006; pp. 101, 193-195.

33. Prat-Bartés, A.; Tort-Martorell, X.; Grima-Cintas, P.; Pozueta-Fernández, L.; Solé-Vidal, I. Métodos Estadísticos, 2nd ed.; UPC: Barcelona, Spain, 2004; p. 376.

34. Stephens, P.W. Phenomenological model of anisotropic peak broadening in powder diffraction. J. Appl. Crystallogr. 1999. [CrossRef]

35. Pero-Sanz Elorz, J.A. Ciencia e Ingeniería de Materiales, 5th ed.; Cie-Dossat: Madrid, Spain, 2006; p. 237.

36. González-Pociño, A.; Alvarez-Antolin, F.; Asensio-Lozano, J. The joint effects of nitriding and parameters related to the destabilisation of austenite on wear resistance in white cast iron with $25 \%$ cr. Metals 2021, 11, 85. [CrossRef]

37. Gonzalez-Pociño, A.; Alvarez-Antolin, F.; Asensio-Lozano, J. Optimization, by means of a design of experiments, of heat processes to increase the erosive wear resistance of white hypoeutectic cast irons alloyed with Cr and Mo. Metals 2019, 9, 403. [CrossRef]

38. Zhou, X.; Fang, F.; Gang, L.I.; Jiang, J. Morphology and properties of M2C eutectic carbides in AISI M2 steel. ISIJ Int. 2010, 50, 1151-1157. [CrossRef] 